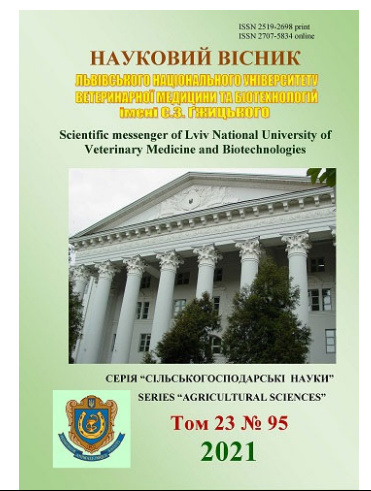

Науковий вісник Львівського національного університету ветеринарної медицини та біотехнологій імені С.3. Гжицького. Серія: Сільськогосподарські науки

\author{
Scientific Messenger of Lviv National University \\ of Veterinary Medicine and Biotechnologies. \\ Series: Agricultural sciences
}

ISSN 2519-2698 print ISSN 2707-5834 online doi: 10.32718/nvlvet-a9527

https://nvlvet.com.ua/index.php/agriculture

UDC 636.2:636.084.52

\title{
Formation of meat productivity of bulls depending on the level of feeding
}

\author{
Ya. I. Pivtorak, I. Yu. Salamakha, I. P. Holodiuk, O. O. Mil, B. S. Denkovich \\ Stepan Gzhytskyi National University of Veterinary Medicine and Biotechnologies Lviv, Ukraine
}

Article info

Received 02.08.2021

Received in revised form 02.09 .2021

Accepted 03.09.2021

Stepan Gzhytskyi National University of Veterinary Medicine and Biotechnologies Lviv,

Pekarska Str., 50, Lviv,

79010, Ukraine.

Tel.: +38-050-522-86-23

E-mail:yaroslavpivtorak@gmail.com
Pivtorak, Ya. I., Salamakha, I. Yu., Holodiuk, I. P., Mil, O. O., \& Denkovich, B. S. (2021). Formation of meat productivity of bulls depending on the level of feeding. Scientific Messenger of Lviv National University of Veterinary Medicine and Biotechnologies. Series: Agricultural sciences, 23(95), 181-185. doi: 10.32718/nvlvet-a9527

The materials of the publication continue to reflect the results of long-term research conducted by the Department of Animal Feeding and Feed Technology on lactating cows and fattening bulls. The aim of the research was to study the peculiarities of the formation of meat productivity by bulls of Volyn meat breed depending on the level of feeding, which in the same diets fully meets the needs of animals in nutrients, namely: dry matter, available energy, protein fraction, carbohydrates, mineral, and biologically active substances. Theoretical issues concerning the organization of complete nutrition of specialized meat breeds with year-round uniform feeding using haylage-type mono-feed are relevant especially in the practice of fattening young animals to obtain veal and young beef. This type of feed according to our recipe is made on the farm "Pchany-Denkovych". More complex feeds of a mixture of three, four, and five components have also been developed, and the field produces compound feed, which is called grain haylage. Diets of this type do not require the use of concentrated feed in livestock fattening. This approach is reflected in the materials of scientific and practical publications on the intensity of functional processes of muscle tissue growth without excess fat. The data obtained in our studies allow us to conclude that there is a direct relationship between the total protein content in muscle tissue and the nutritional qualities of diet food. It is such components of mono-feed as corn cobs of milk-wax ripeness and soybean pods that provide a relatively high protein content in the feed, which provided high average daily gains in live weight with a limited number of concentrates. The control slaughter of bulls at the end of the experiment showed that the average preslaughter live weight was at the level of 541-501 kg. Slaughter yield of carcasses was directly dependent on the structure of the diet with a small group difference, which was in the range of $0.8-1.2 \%$ compared to the first group, whose diet compensated for the need of animals for energy and protein through concentrates and was usually more expensive. Thus, the replacement of some concentrates in terms of the nutritional value of the second and third groups does not lead to a significant negative impact on the morphological composition of carcasses, which gives reason to believe the effectiveness of such diets. Studies on fattening bulls of the Volyn meat breed give grounds to claim that the harvest of mono-feed (corn-soybean) haylage type, the nutritional value of which is more than 0.5 feed. from contains a sufficient amount of protein, carbohydrates, vitamins, and minerals, provides high average daily gains in live weight, and has a positive effect on the quality of young beef. The production of this type of fodder allows producing 78.1-99.8 quintals of fodder from 1 ha of fodder area, respectively. from and 6.1-13.9 quintals of digestible protein and makes it possible to reduce the cost of concentrated feed in the structure of animal diets for fattening.

Key words: fattening bulls, structure of rations, average daily gains, live weight, mono-feed, concentrates, slaughter rates, slaughter products.

\section{Формування м'ясної продуктивності бугайців в залежності від рівня годівлі}

\author{
Я. І. Півторак, І. Ю. Саламаха, І. П. Голодюк, О. О. Міль, Б. С. Денькович
}

Львівський національний університет ветеринарної медицини та біотехнологій імені С. 3. Гжсиького, м. Львів, Украӥна 
У матеріалах публікаиії продовжують відображатися результати тривалих наукових досліджень, які веде кафедра годівлі тварин і технологї кормів на лактуючих коровах та відгодівельних бугайцях. Завданням досліджень було вивчити особливості формування м'ясної продуктивності організмом бугайців волинської м'ясної породи в залежності від рівня годівлі, яка за однотипних раціонів повністю забезпечує потребу тварин у поживних речовинах, а саме: сухій речовині, доступній енергії, фракційному складі протеїну, вуглеводів, мінеральних та біологічно-активних речовинах. Теоретичні питання щчодо організачї повночінного живлення худоби спеціалізованої м'ясної породи за иілорічно однотипної годівлі з використанням монокорму сінажного типу $є$ актуальним особливо в практиці відгодівлі молодняку з метою отримання м'яса телятини та молодої яловичини. Такий вид корму за запропонованим нами рецептом виготовляється в фермерському господарстві “Пчани-Денькович”. Розроблено також більш складні кормо сумішки трьох-чотирьох $і$ п'яти компонентні, за принципом поле виготовляє комбікорм, який дістав назву зерносінаж. Рачіони такого типу не вимагають використання концентрованих кормів при відгодівлі худоби. Саме такий підхід відображено у матеріалах науково-практичної публікації щодо інтенсивності функціональних процесів росту м'язевої тканини без надлишку жирової. Отримані у наших дослідженнях дані дозволяють зробити висновок про пряму залежність між загальним вмістом білку в м'язевій тканині і поживними якостями кормів раціону. Саме такі компоненти монокорму, як зерно качанів кукурудзи молочно-воскової стиглості та стручків сої забезпечують порівняно високий вміст протеӥну в кормі, щуо забезпечило високі середньодобові прирости живої маси при обмеженій кількості концентратів. Проведений контрольний забій бугайців в кінці досліду показав, шуо середня перед забійна жива маса знаходилась на рівні 541-501 кг. Забійний вихід туші мав пряму залежність від структури раціону з незначною між груповою різницею, яка знаходилась в межах 0,8-1,2 \% по відношенні до першої групи, раціон якої компенсував потребу тварин в енергї та протеїні за рахунок концентратів $і$ звичайно був дорожчим. Таким чином заміна частини концентратів за поживністю другої $і$ третьої груп не призводить до суттєво негативного впливу на морфологічний склад туш, щуо дає підставу стверджувати про ефективність таких раціонів. Проведені дослідження на відгодівельних бугайцях волинської м'ясної породи дають підставу стверджувати, шчо заготівля монокорму (кукурудзяно-соєвого) сінажного типу поживність якого становить понад 0,5 корм. од. містить достатню кількість протеїну, вуглеводів, вітамінів та мінеральних солей, забезпечує високі середньодобові прирости живої маси і позитивно впливає на якісні показники м'яса молодої яловичини. Виробництво такого виду корму дозволяє з 1 га кормової площуі виробляти відповідно 78,1-99,8 и корм. од. та 6,1-13,9 и перетравного протеїну та дає можливість змениити витрати концентрованих кормів в структурі раціонів тварин на відгодівлі.

Ключові слова: відгодівельні бугайці, структура раціонів, середньодобові прирости, жива маса, монокорм, концентрати, забійні показники, продукти забою.

\section{Вступ}

Виробництво яловичини тісно пов'язане 3 типом годівлі худоби та пропорційно відповідає максимальному використанню основного виду корму в структурі кормового раціону, а також в значній мірі залежить від породи великої рогатої худоби, поставленої на відгодівлю та їх догляду та утримання. Практика застосування цілорічної однотипної годівлі на раціонах 3 використанням моно кормів викликає особливу зацікавленість у науковців в технології промислової відгодівлі молодняку великої рогатої худоби (Franklin et al., 2005; Stojevic et al., 2005; Lomax \& Calder, 2009; Dehghan-Banadaky et al., 2013; Denkovich et al., 2019).

Теоретичні питання щодо організації повноцінної годівлі худоби спеціалізованих м'ясних порід продовжують вивчатися. Спрямування цих досліджень різноманітне, але всі вони направлені на пошуки но- вих альтернативно дешевих кормових засобів, які б здешевлювали виробництво м'яса яловичини не погіршуючи при цьому іiі якісні показники (Kim et al., 2011; Masanetz et al., 2011; Vovk \& Polovyi, 2020; Borshch \& Borshch, 2021; Mylostyvyi et al., 2021).

Метою досліджень було вивчення особливостей інтенсивності росту та м'ясної продуктивності відгодівельних бугайців волинської м'ясної породи в залежності від віку, рівня годівлі з врахуванням енергетичного та протеїнового живлення.

\section{Матеріал і методи досліджень}

Науково-господарський дослід проводився в умовах фермерського господарства "Пчани-Денькович" Жидачівського району Львівської області за схемою наведеною у табл. 1.

\section{Таблиця 1}

Схема науково-виробничого досліду, $\mathrm{n}=10$

\begin{tabular}{|c|c|c|}
\hline $\begin{array}{c}\text { Група піддослідних } \\
\text { тварин } \\
\end{array}$ & $\begin{array}{l}\text { Тривалість досліду, } \\
\text { діб }\end{array}$ & $\begin{array}{l}\text { Особливості годівлі: структура раціонів інтенсивного періоду } \\
\text { вирощування }\end{array}$ \\
\hline 1 контрольна & 300 & $\begin{array}{l}\text { ОР - грубі (сіно - } 20 \text { \%), соковиті (монокорм сінажного типу - } 50 \text { \%, } \\
\text { комбікорм }-30 \%)\end{array}$ \\
\hline 2 дослідна & 300 & ОР - заміна 20 \% комбікорму за поживністю на монокорм \\
\hline 3 дослідна & 300 & ОР - заміна 30 \% комбікорму за поживністю на монокорм \\
\hline
\end{tabular}

Раціони годівлі піддослідних тварин були збалансовані за вмістом поживних речовин з врахуванням сухої речовини, доступної енергії та протеїну, а також включенням в склад комбікорму солево-мінерального преміксу.

За час проведення досліду було вивчено і проаналізовано наступні показники: хімічний склад і поживну цінність виготовленого монокорму та комбікорму перед початком досліду і протягом проведення досліду в умовах сертифікованої лабораторії ЛНУВМБ імені С. 3. Гжицького; повноту поїдання кормів тваринами; живу масу піддослідних бугайців; динаміку їх середньодобових приростів у різні вікові періоди.

По завершенні відгодівлі з кожної групи було відібрано по 3 голови типових тварин і проведено контрольний забій у забійному цеху з послідуючою обвал- 
кою.

Було визначено: живу масу при знятті з відгодівлі, передзабійну живу масу, масу туші, масу внутрішнього жиру, забійний вихід туші.

За результатами обвалки враховувалась сортність м'яса, кількість м'язевої кісткової і сполучної тканини. Було відібрано середні зразки для визначення хімічного складу та оцінки якісних показників.

Отримані результати піддавались статистичній обробці за допомогою загальноприйнятих методів варіаційної статистики з оцінкою середньо арифметичної похибки і розрахунками вірогідності різниць за методом Стюдента з використанням програмного забезпечення Micros of Exel.

\section{Результати та їх обговорення}

Головним завданням проведених досліджень було отримання молодої яловичини в найбільш оптимальні терміни вирощування. Адже відомо, що попит на телятину і молоду яловичину надзвичайно високий, ось чому одним і вагомих чинників однотипної відгодівлі худоби особливо спеціалізованих м'ясних порід $\epsilon$ рівень ефективності засвоєння поживних речовин раціону. Отже, виходячи з поставленого завдання про інтенсивність росту піддослідних бугайців можна підтвердити позитивну оцінку їі ефективності. Показники приростів живої маси піддослідних тварин наведено у (табл. 2).

\section{Таблиця 2}

Динаміка продуктивності бугайців піддослідних груп $(\mathrm{M} \pm \mathrm{m}, \mathrm{n}=10)$

\begin{tabular}{lcccc}
\hline \multirow{2}{*}{ Група } & \multicolumn{3}{c}{ Середньодобові прирости, г } & \multirow{2}{*}{ Жива маса при знятті, } \\
\cline { 2 - 4 } & 6 місяців & 9 місяців & 12 місяців & $541 \pm 9,3$ \\
1 контрольна & $905 \pm 8,4$ & $1120 \pm 10,7$ & $1210 \pm 10,7$ & $515 \pm 9,0$ \\
2 дослідна & $893 \pm 7,6$ & $1080 \pm 16,0$ & $1160 \pm 10,6$ & $501 \pm 8,1$ \\
2 дослідна & $769 \pm 9,7$ & $989 \pm 13,4$ & $1030 \pm 11,0$ & \\
\hline
\end{tabular}

Аналіз приростів живої маси піддослідного молодняку за період досліду свідчить про те, що в першій групі в 6-місячному віці вони складали в середньому 905 г і перевищували показники тварин другої і третьої груп відповідно на 1,33 і 15,02 \%. Подібна тенденція спостерігається у віці 9 та 12 місяців, що можна пояснити вищою кількістю концентратів у раціоні тварин цієї групи, що відповідно призводить до підвищення вартості відгодівлі у виразі економічної ефективності.

Після завершення заключного періоду відгодівлі було проведено контрольний забій піддослідних бугайців (табл. 3).

Таблиця 3

Забійні якості піддослідних бугайців $(\mathrm{M} \pm \mathrm{m}, \mathrm{n}=3)$

\begin{tabular}{lccc}
\hline Група & Перед забійна жива маса, кг & Маса охолодженої туші, кг & Забійний вихід, \% \\
\hline 1 контрольна & $541 \pm 9,3$ & $298 \pm 2,4$ & $55,5 \pm 1,3$ \\
2 дослідна & $515 \pm 9,0$ & $275 \pm 3,0$ & $54,7 \pm 1,2$ \\
3 дослідна & $501 \pm 8,1$ & $269 \pm 2,8$ & $54,3 \pm 1,1$ \\
\hline
\end{tabular}

Одержані результати показали, що середня перед забійна жива маса бугайців знаходилася на рівні 541501 кг. Забійний вихід туші мав пряму залежність від структури раціону з незначною між груповою різницею, яка знаходилася в межах 0,8-1,2 \% по відношенні до першої групи, раціон якої компенсував потребу тварин в енергії та протеїні за рахунок концентратів і звичайно був дорожчим.

Таким чином, заміна частини концкормів за поживністю другої і третьої групи не призводить до суттевого негативного впливу визначені показники, що дає підставу стверджувати про ефективність таких раціонів, а також це підтверджують показники морфологічного складу туш, які відображенні у табл. 4.

Таблиця 4

Морфологічний склад туш ( $\mathrm{M} \pm \mathrm{m}, \mathrm{n}=3$ )

\begin{tabular}{|c|c|c|c|c|c|c|}
\hline \multirow{3}{*}{ Група } & \multirow{3}{*}{$\begin{array}{c}\text { Маса охолодженої } \\
\text { туші, кг }\end{array}$} & \multicolumn{5}{|c|}{ Сортовий розподіл тканин, кг } \\
\hline & & \multicolumn{3}{|c|}{ м'язевої } & \multirow{2}{*}{ жирової } & \multirow[b]{2}{*}{ кісткової } \\
\hline & & вищий & перший & другий & & \\
\hline 1 контрольна & $298 \pm 2,4$ & 46 & 115 & 94 & 6 & 37 \\
\hline 2 дослідна & $275 \pm 3,0$ & 45 & 105 & 86 & 5 & 34 \\
\hline 3 дослідна & $269 \pm 2,8$ & 43 & 103 & 85 & 5 & 33 \\
\hline
\end{tabular}

Проведене обвалювання туш вказує на те, що всі туші піддослідних бугайців відповідали першій категорії з явно вираженим жировим поливом. При цьому різна кількість концентратів в структурі раціонів по різному вплинула на сортовий розподіл м'яса. Незначну перевагу в кількості м'язової тканини вищого i першого сорту мали бугайці першої групи. Вищою була в цій групі і кількість жирової тканини. Слід 
відзначити, що бугайці другої і третьої груп за кількістю і якістю м'яса суттєвої різниці між собою не мали.
Для проведення хімічного аналізу м’яса було відібрано середні зразки та проведена порівняльна оцінка їх складу (табл. 5).

Таблиця 5

Хімічний склад м’яса піддослідних бугайців, \% $(\mathrm{M} \pm \mathrm{m}, \mathrm{n}=3)$

\begin{tabular}{lcccc}
\hline \multirow{2}{*}{ Група } & \multicolumn{3}{c}{ Показник } \\
\cline { 2 - 5 } & вода & білок & жир & Відношення білку до \\
жиру & $1,0 \pm 0,05$ \\
\hline 1 контрольна & $72,5 \pm 0,14$ & $15,7 \pm 0,02$ & $1,0 \pm 0,04$ & $1,43: 1$ \\
2 дослідна & $71,5 \pm 0,14$ & $16,3 \pm 0,03$ & $10,5 \pm 0,02$ & $1,4 \pm 0,03$ \\
3 дослідна & $71,7 \pm 0,14$ & $18,6 \pm 0,03$ & $10,8 \pm 0,02$ & $1,0 \pm 0,04$ \\
\hline
\end{tabular}

Аналіз отриманих даних хімічного складу показав, що за вмістом білку м'яса бугайців другої і третьої груп на 1,2 і 2,9 \% переважало першу. Така аналогія спостерігалася і за вмістом жиру. Відношення білка до жиру. Відношення білка до жиру найбільш оптимальним було у бугайців, які відгодовувалися на раціоні з обмеженою 20-30 \% кількість концентратів. Такі раціони були найбільш оптимальними, як у поживному відношенні так і у зворотному еквівалентні.

Проведена грошова оцінка даного типу відгодівлі худоби підтвердила наші очікування відносно використання монокорму сінажного типу взамін частини концентратів у складі раціону цілорічної однотипної годівлі бугайців. Так, при незначному зниженні середньодобових приростів дослідних групах затрати корму на 1 кг живої маси у кормових одиницях, а також у МДж обмінної енергії знаходилися в межах 8,7-8,9 і 87-89 відповідно, та не перевищує розроблених економічних норм для тварин на відгодівлі.

\section{Висновки}

Проведені дослідження на відгодівельних бугайцях волинської м'ясної породи дають підставу стверджувати, що заготівля монокорму (кукурудзяносоєвого) сінажного типу поживність якого становить понад 0,5 корм. од. містить достатню кількість протеїну різних за розчинністю фракцій, вуглеводів, вітамінів та мінеральних солей, забезпечує високі середньодобові прирости живої маси і позитивно впливає на якісні показники м'яса молодої яловичини. Виробництво такого виду корму дозволяє з 1га кормової площі виробляти відповідно 78,1-99,8 ц корм. од. та 6,113,9 ц перетравного протеїну та дає можливість зменшити витрати концентрованих кормів в структурі раціонів тварин на відгодівлі.

\section{References}

Borshch, O. O., \& Borshch, O. V. (2021). Evaluation of first-born cows of different genotypes on the indicators of udder development and milk production. Scientific Messenger of Lviv National University of Veterinary Medicine and Biotechnologies. Series: Agricultural sciences, 23(94), 36-41. doi: 10.32718/nvlveta9407.

Dehghan-Banadaky, M., Ebrahimi, M., Motameny, R., \& Heidaria, S.R. (2013). Effects of live yeast supple- mentation on mid-lactation dairy cows performances, milk composition, rumen digestion and plasma. Appl. Anim. Res., 41, 137-142. http://agris.fao.org/agrissearch/search.do?recordID=US201400122416.

Denkovich, B.S., Kharko, M.V., \& Pivtorak, Y.I. (2019). Hematological indices of cows and their milk production for use in the composition of the diet of the drug "Biosprint". Scientific Messenger of Lviv National University of Veterinary Medicine and Biotechnologies. Series: Agricultural sciences, 21(90), 32-36. doi: 10.32718/nvlvet-a9006.

Franklin, S. T., Newman, M. C., Newman, K. E., \& Meek, K.I. (2005). Immune parameters of dry cows fed mannan oligosaccharide and subsequent transfer of immunity to calves. J. Dairy Sci., 88(2), 766-775. doi: 10.3168/jds.S0022-0302(05)72740-5.

Kim, M. H., Seo, J. K., Yun, C. H., Kang, S. J., Ko, J. Y., \& Ha, J. K. (2011). Effects of hydrolyzed yeast supplementation in calf starter on immune responses to vaccine challenge in neonatal calves. Animal. Sci., 5(6), 953-960. doi: 10.1017/S1751731110002673.

Lomax, A. R., \& Calder, P. C. (2009). Prebiotics, immune function, infection and inflammation. A review of the evidence. Br. J. Nutr., 101(5), 633-658. doi: $10.1017 /$ S0007114508055608.

Masanetz, S., Preißinger, W., Meyerand, H. H. D. \& Pfaffl, M. W. (2011). Effects of the prebiotics inulin and lactulose on intestinal immunology and hematology of preruminant calves. Animal Sci., 5(7), 1099-1106. doi: 10.1017/S1751731110002521.

Mylostyvyi, R., Lesnovskay, O., Karlova, L., Khmeleva, O., Kalinichenko, O., Orishchuk, O., Tsap, S., Begma, N., Cherniy, N., Gutyj, B., \& Izhboldina, O. (2021). Brown Swiss cows are more heat resistant than Holstein cows under hot summer conditions of the continental climate of Ukraine. J Anim Behav Biometeorol, 9(4), 2134. doi: 10.31893/jabb.21034.

Mylostyvyi, R., Sejian, V., Izhboldina, O., Kalinichenko, O., Karlova, L., Lesnovskay, O., Begma, N., Marenkov, O., Lykhach, V., Midyk, S., Cherniy, N., Gutyj, B., \& Hoffmann, G. (2021). Changes in the Spectrum of Free Fatty Acids in Blood Serum of Dairy Cows during a Prolonged Summer Heat Wave. Animals, 11(12), 3391. doi: 10.3390/ani11123391.

Stojevic, Z., Pirsljin, J., Milinkovic-Tur, S., Zdelar-Tuk, M., \& Beer Ljubic, B. (2005). Activities of AST, ALT and GGT in clinically healthy dairy cows during lacta- 
tion and in the dry period. Veterinarski arhiv, 75(1), 67-73. URL: https://hrcak.srce.hr/67059.

Vovk, S. O., \& Polovyi, I. V. (2020). Scientific and practical aspects of the use of prebiotics in the process of feeding ruminants. Scientific Messenger of Lviv National University of Veterinary Medicine and Biotechnologies. Series: Agricultural sciences, 22(92), 9-14. doi: $10.32718 /$ nvlvet-a9202. 